\title{
Poaching and illegal wildlife trade in western Argentina
}

\author{
Sofía Becerra ${ }^{1,2}$, José Marinero ${ }^{3}$ and Carlos E. Borghi ${ }^{1,2,4 *}$
}

\begin{abstract}
Human-wildlife interactions, poaching and illegal wildlife trade in particular, are among the major threats to biodiversity around the world, causing species and population extinctions, zoonotic diseases dissemination, and exotic species invasions, among others. Here we assessed the patterns of poaching and illegal wildlife trade in western Argentina. We reviewed official infringement and verification records for 5 years (2015 to 2019) in San Juan province. We assessed the taxa involved and their conservation status, including wildlife uses and poaching elements. We found 58 taxa involved in 697 records. Most of them were birds $(72 \%)$, followed by mammals $(26 \%)$ and reptiles $(2 \%)$. However, mammals are proportionally the most poached taxon in relation to their richness in the region. We detected that the bird Saltator aurantiirostris was the most prevalent species, appearing in $63 \%$ of all records, while Diuca diuca, the second most seized species, appeared in $19 \%$ of the infringement proceedings. This study shows that illegal hunting and trafficking are frequent activities affecting many species in the province, and that mammals and birds are the most affected taxa. Mammals were mostly involved in poaching events for their meat and fur, for which individuals were killed. On the other hand, birds were mainly live-captured to be sold as pets. Actions are necessary to protect fauna and raise people's awareness in order to effectively control these illegal activities and support ecosystem health and integrity. To tackle these problems, it is fundamental to understand the impacts of poaching and trade, improve state control to prevent these activities, and employ non-formal education actions to change people's behavior towards conservation.
\end{abstract}

Keywords: Illegal Wildlife Trade; Trafficking; Pet Trade; Songbirds.

1 Departamento de Biología, FCEFN, Universidad Nacional de San Juan, Av. Ignacio de la Roza y Meglioli, San Juan J5402DCS, Rivadavia; San Juan, Argentina

2 INTERBIODES (Grupo de Investigación en Interacciones Biológicas en el Desierto).

3 Secretaría de Estado de Ambiente y Desarrollo Sustentable, Provincia de San Juan, Argentina.

4 Centro de Investigaciones de la Geósfera y la Biósfera (CIGEOBIO) Consejo Nacional de Investigaciones Científicas y Facultad de Ciencias Exactas, Físicas y Naturales, Universidad Nacional de San Juan.

* Corresponding author $\bowtie$. E-mail address: SB (sofiabecerra296@gmail.com), JM (marinero.jose@gmail.com), CEB (cborghi@unsjcuim.edu.ar)

Part of Special Issue:

Use, Management and Conservation of Wildlife in Latin America.

Edited by Hani R. El Bizri, Melina S. Simoncini, Jair H. Castro Romero, Alejandro Meléndez Herrada, Joaquín L. Navarro. 


\section{SIGNIFICANCE STATEMENT}

This work is the first to analyze information from offence records on poaching and illegal wildlife trade in western Argentina, and one of the few that addresses this issue in the country. While previous studies have emphasized the role of trade and use of large animals, mainly mammals such as camelids, our study shows that the use and trade of live small birds as pets are the most important wildlife utilization types in this region. Raising small birds as pets is deeply rooted in society; therefore it is necessary not only to improve state control to prevent their hunting and trade, but also to employ non-formal education actions to change people's behavior towards conservation of this group.

\section{INTRODUCTION}

The world is currently facing a critical biodiversity loss, the sixth mass extinction according to some authors (Barnosky et al. 2011; Butchart et al. 2010; Dirzo et al. 2014; Pimm et al. 1995). It is estimated that between 1970 and $2014,60 \%$ of wild populations have been lost. In Central and South America, these losses have been more dramatic, reaching up to $89 \%$ of species (WWF 2018). Recent studies show that the threats of old (hunting, fishing, or logging) are still the main drivers of species loss, whichever taxonomic group is involved. Overexploitation and agriculture put at risk more than 8,500 species (listed as threatened or near-threatened; IUCN 2021). Seventy-two percent of species in that red list are overexploited for commerce, recreation, or subsistence. Added to this is the collection of individuals for the pet trade and medicinal or religious purposes (Maxwell et al. 2016; Van Uhm 2016). Currently, illegal harvest of wildlife resources (or poaching) is one of the central problems of global biodiversity, inducing the reduction or extinction of wildlife populations (Bennett and Robinson 2000b; Eliason 1999; Gavin et al. 2010).

The illegal wildlife trade is generally associated with the extraction of individuals from their habitat. Some studies estimate that the illegal wildlife trade moves between US $\$ 7$ billion and US $\$ 25$ billion annually (Interpol 2012; Liddick 2011; Nellemann et al. 2016; Schneider 2008; Van Uhm 2016). Poaching and illegal wildlife trade represent a conservation risk at different levels. For example, overexploitation may destabilize intra- and interspecific ecological relationships and generate unhealthy ecosystems that do not satisfy the necessary functions for their maintenance, as they become impoverished or empty. Such effects were already observed in areas such as the Lacandona's jungle in Mexico, and the Gran Chaco in Argentina, Bolivia, Paraguay, and southeast of Brazil (Fraser et al. 2019; Periago et al. 2015; Wilkie et al. 2011). Throughout history, humans have used wildlife for multiple purposes. In America, after the European colonization, millions of individuals of wild species were exported for commerce, feeding, clothes, medicine, and pets. Argentina was no exception, and during 19th and the first half of the 20th cen- tury, many individuals were hunted indiscriminately for local or international consumption. However, even though wildlife hunting and trade is an ancient activity, the current rates of these activities in South America are poorly known. In different countries of the subcontinent, studies on this activity are still few and fragmentary (Arroyave et al. 2014; Bertonatti 2017; Grisolia and Grosskopf 2021; Sosa-Escalante 2011).

In Argentina, several studies about the uses of fauna were conducted in the 80s (Jackson 1986; Mares and Ojeda 1984; Ojeda and Mares 1982), but few studies have been done since then (Borghi et al. 2017; Hernandez et al. 2015). Around 1980, the legal export of meat, leather, and fur was allowed for almost all wild species. In 1978 alone, the furs/pelts of 2,673,115 coypus (Myocastor coypus); 980,015 grey foxes (Lycalopex griseus), and 112,364 Geoffroy's cats (Leopardus geoffroyi) were legally exported, to name a few. This threat had brought a lot of species to the brink of extinction. The case of the short-tailed chinchilla (Chinchilla chinchilla), for instance, stands out; the species was hunted for its fur and is now considered critically endangered in Argentina (Chebez and Chevez 2008). Given this high pressure on Argentinian wildlife (Jackson 1986; Mares and Ojeda 1984; Ojeda and Mares 1982), some laws were enacted at that time to mitigate overexploitation, such as the first "National Law on Hunting and Protection of Fauna," in 1950 (Argentine National Law 13,908), and the Law on "Protection and Conservation of Wild Fauna" in 1981 (Argentina National Law 22,421).

However, in a recent study, Bertonatti (2017), using information from news on seizures from the Internet, found that more than 7,500 wild animals and more than 8,000 plants (with or without life) were involved in 38 poaching and wildlife trade crimeevents. The alarming part of these results is that, in general, seizures are only a small fraction of the illegal wildlife trade (Van Uhm 2016), highlighting that wildlife trade is still a pervasive threat to the conservation of wildlife in Argentina.

Using official surveillance records as our source of data, and considering that this type of information is crucial to obtain an adequate diagnosis of illegal wildlife trade, we set out to answer the following questions: 1) What are the fauna species targeted for 
poaching and illegal trade in western Argentina? 2) What are the hunting tools used by poachers? And 3) What are the motives for these crimes? Our results are useful to unveil the rates of poaching and trade and to inform effective strategies to curb these activities in Argentina.

\section{MATERIAL AND METHODS}

\section{Study area and data collection}

San Juan is an Argentine province located in the west of the country, next to the Andes mountain range. Almost all the province has an arid climate, with an average annual rainfall of around $100 \mathrm{~mm}$ (Figure 1). Data were obtained based on the official infringement and verification records of the Secretary of Environment and Sustainable Development (Secretaría de Ambiente y Desarrollo Sustentable, provincia de San Juan), related to poaching, possession, and illegal wildlife trade, corresponding to the years between 2015 and 2019.

Different sources from the literature were used to categorize the conservation status of the species recorded at different scales at the international level (IUCN 2021), at the National level - for mammals (SAyDS-SAREM 2019), birds (MAyDS 2017), and reptiles (Giraudo et al. 2012) - and at the provincial level (Res. SAyDS No. 656-11 2011).

\section{Characterization of poaching activities}

The date, implicated taxa (quantitative and qualitatively), and hunting tools were recorded for each infringement and verification record. All this information was organized in spreadsheets for its subsequent analysis and each record was verified to avoid duplicates.

Implicated species were classified as "killed animals" when the specimens were dead and were used to obtain meat, leather, or other by-product from the same source (for own consumption or sale); and as "trapped animals" when the specimens were alive, as is the case with songbirds and other animals used as pets (Sousa and Srbek-Araujo 2017). In the few cases $(\mathrm{n}=3)$ of records that included both trapped and killed animals, the values were added to "killed animals."

Individuals that could not be unequivocally identified at the species level were pooled in a higher taxonomic level (i.e. armadillos were treated as "armadillos"; bird species of the genus Sicalis and some individuals of the genus Turdus were pooled at the genus level). All parrots and parakeets not identified at the species level were pooled within the order Psittaciformes. The individuals called "hare" without speci- fying the species were not taken into account because they could correspond to either individuals of the native maras (Dolichotis patagonum, rodent) or to European hares (Lepus europaeus, exotic lagomorph). Taking into account those cases, we use the word "taxa" throughout this document to refer to species, genus, family and/or order.

\section{Data analysis}

Descriptive statistics, bar diagrams, and nonparametric statistics were used to analyze the data. We analyzed the number of poached individuals per species and the frequency of poaching and trade among the different vertebrate taxa.

Seized taxa were quantified using the seizure index. This index is the mean of two measures of importance: percetage of occurrence of a taxon among infringement records, and percentage of total seizure numbers of each taxon among the infringement records. Finally, we estimated the seizure index as the percentage of the value for each taxon with respect to the maximum value reached for any taxon. Therefore, the highest value reached by at least one taxon is $100 \%$. Consequently, this index should be free from the biases present when any of those procedures is used singly. To our knowledge, this is the first publication using an seizure index method for seizure data.

Chi-square goodness-of-fit test was performed to compare the use made of the different vertebrate taxa. When comparing the number of poached individuals of the different taxa with the expected frequency, as the proportion to the richness of each taxonomic group in the San Juan province, we have combined amphibians and reptiles to ensure that the expected frequencies in the table were not less than 5 . When comparing species, we only used frequency of birds and mammals for the same reason. We also performed a binomial test to compare the proportion of exotic vs native species seized. The criterion for significance was $p<0.05$. Results are expressed as the untransformed mean $\pm S E$.

\section{RESULTS}

\section{Description of seized species}

A total of 693 records related to poaching and illegal wildlife trade between 2015 and 2019 were reviewed, with an average of $138( \pm 19.11)$ records per year, involving 58 different vertebrate taxa. The majority of the taxa seized were related to trapped animals (still alive; $78 \%$ ), while the remaining $22 \%$ involved killed animals. 


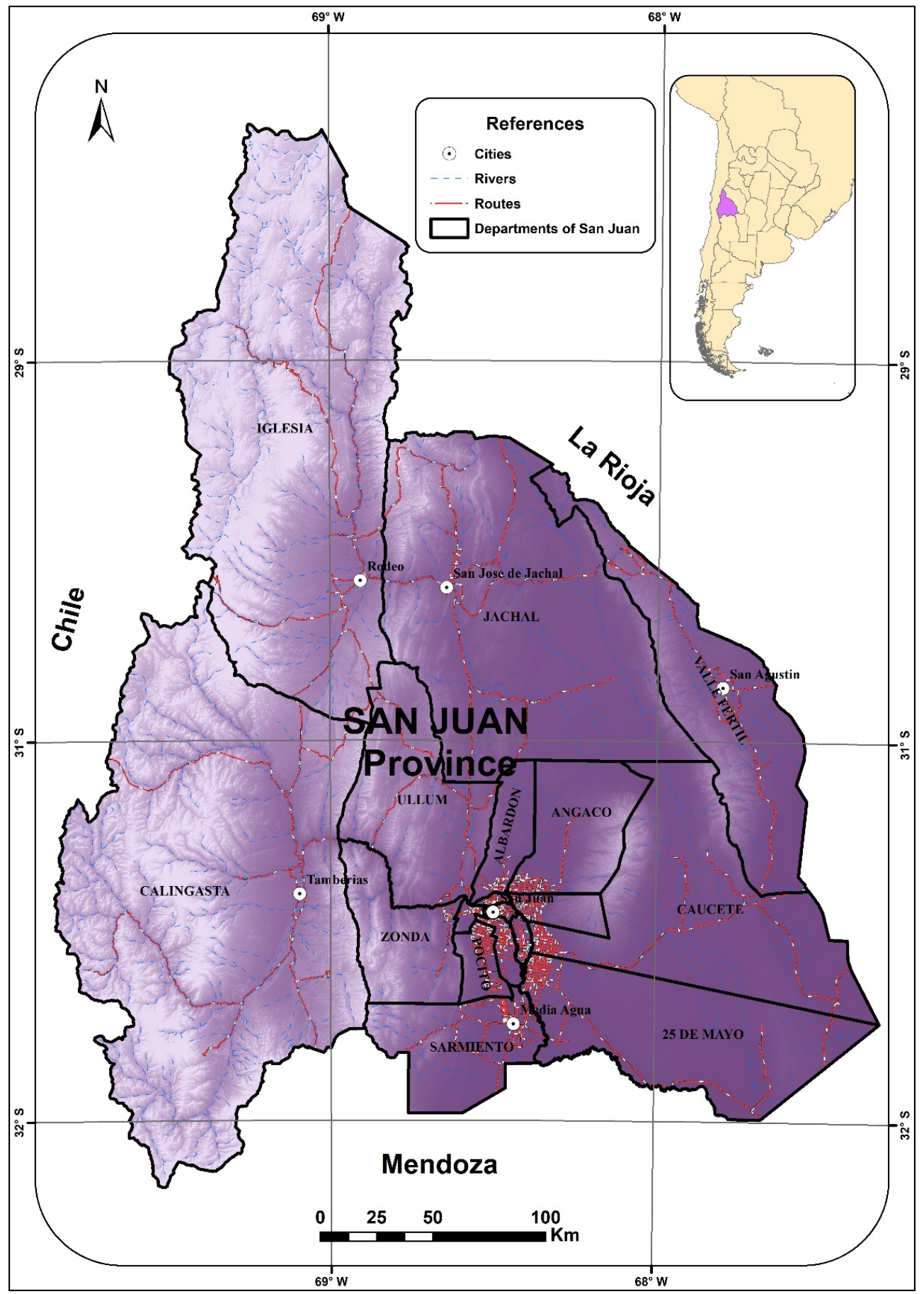

Figure 1: Map showing the location of San Juan province, in western Argentina, its political divisions, capital cities, rivers and paved routes.

From 2015 to $2019,1,938$ individuals of different vertebrate taxa were involved in poaching and/or illegal trade. Among them, we found 1,791 birds, 146 mammals, and 1 reptile (Table 1, Figure 2). If we take into account the number of taxa found in the seizures, the greater percentages correspond to birds $(72 \%, 42$ taxa) and mammals $(26 \%, 15$ taxa). The remaining percentage corresponds to reptiles ( $2 \%, 1$ taxon). No amphibian seizure was registered in the studied period (Table 2). These taxa belong to 16 orders, 29 families and 50 genus. Table 4 shows the list of vertebrate taxa seized, their conservation status in international, national and province level whether each species is native or exotic to the province (MAyDS- 
AA 2017, SAyDS-SAREM 2019), and the motivations for hunting the taxa. The proportion of species seized showed significantly fewer exotic than native species (11/58; binomial test, $p<0.0001)$.

Poached individuals of the different taxonomic groups were not hunted proportionally to the richness of each taxon in the San Juan province $(\mathrm{p}<0.0001)$. We observed the same when we analyzed the proportion of species seized (only mammals and birds) (Table 2). Regarding mammals, they were captured $173 \%$ more than expected, while birds were caught in almost the same proportion as expected $(+0.77)$. Reptiles and amphibians, on the other hand, were less captured than expected (-1\%).

The taxas with the highest seizure indexes were all birds, among which the four with the higher values were Saltator aurantirostris (golden-billed saltator, 100), Diuca diuca (common diuca finch, 41.6), Sicalis spp. (yellow finch, 32.0) and Cyanocompsa brissoni (ultramarine grosbeak, 7.5). Mammals only appear in 6th and 7th places; those with the highest indices were D. patagonum (mara, 6.7) and L. guanaco (guanaco, 6.1) (Table 4).

In relation to their conservation status, there are 16 seized species included in some category of threat of which six are mammals $(38 \%)$ and 10 are birds $(62 \%)$ (Table 2; Figure 3). Those with the highest seizure indexes are $S$. aurantiirostris and C. brissoni among the birds, and D. patagonum and L. guanicoe among mammals (Table 4).

When analyzing the international conservation status of the seized birds, among the species threatened are the yellow cardinal (Gubernatrix cristata), and both rhea species (Rhea americana and R. tarapacensis). The situation at national and provincial level is similar, but more songbirds are included such as the golden-billed saltator (S. aurantiirostris) and the black-backed grosbeak (Pheucticus aureoventris) (Table 4). Finally, for reptiles, only one killed individual of the non-threatened Crotalus durissus was registered.

With regard to hunting tools that were seized by provincial rangers from poachers, most were related to hunting live birds for pets ( $64 \%$; Table 3$)$, such as bird traps, bird cages, mist nets and glue for trapping birds. Second in representativeness were the tools used to hunt mammals and rheas, such as firearms, ammunition, greyhound dogs, knives and flashlights. Other hunting tools appear in very small numbers, such as fox traps and Sherman traps for rodents. Finally, it is interesting to highlight that seven "boleadoras" (weapons made by leather cords and stone balls) were seized, weapons used by native peoples that are still used today to hunt rheas by criollo people.

With respect to the motivations for hunting wildlife, most of the taxa hunted were to be used or sold for the purpose to be used as pets (78\%; Figure 4: Table 4). To a lesser extent, the motivations for poaching was to obtain meat, leather, feathers, and fiber for weaving, or as sport hunting.

\section{DISCUSSION}

The confiscated individuals of terrestrial vertebrates seized in the west of Argentina, San Juan province, belong to 58 different taxa, grouped into three faunal groups (mammals, birds, and reptiles). Most of them is native of the province (81\%; Table 4). Among birds, native taxa that are under greater pressure of poaching and illegal wildlife trade are Saltator aurantiirostris, Diuca diuca, Sicalis spp., Cyanocompsa brissoni, and Phrygilus gayi. Among mammals, we can found Dolichotis patagonum, Lama guanicoe, armadillos, Lagostomus maximus and Puma concolor. Only one reptile, a venomous snake Crotalus durissus killed were seized. The high number of species used in this region is highlighted. Previous studies in this area had reported only 18 taxa of vertebrates used for a more geographic area that include the west of Argentina (Vilela et al. 2009), 56 vertebrate taxa used by local communities were reported by Barbaran (2017) at the nort of Argentina, including a subtropical forest area, and Alves-Barbosa et al. (2011) reported the use of 32 vertebrate taxa in a traditional community at a semiarid region of Brazil.

Among the species categorized as exotic, there are taxa from other continents, such as Lepus europaeus or Sus scrofa, and vertebrates whose natural habitat does not include the province of San Juan, as is the case of the talking parrot (Amazona aestiva), a threatened species highly valued as a pet, that occur at the north of Argentina (Leite et al. 2008), the toucan (Ramphastos toco), and the red-capped cardinal (Paroaria coronata), amont others. The presence of this species indicates that it is likely that the province is included in illegal trafficking networks that exist nationwide and put many species at risk. An example of the existence of these networks in Argentina was exposed by Richard et al. (2010), who showed the links of illegal trade networks from Santiago del Estero to Buenos Aires.

With respect to the hunting tools, the majority of them were related with hunting of live birds. Firearms and ammunition occurred in smaller numbers and were related to hunting for meat and leather. These results contrast with those obtained by studies elsewhere, in which the most common tools seized or found in surveys are firearms, such as in Côte d'Ivoire (Yéboué et al. 2020), in the Atlantic Forest (Sousa and Srbek-Araujo 2017) in the semiarid region of Brazil (Alves et al. 2009), and in Gabon (Carpaneto et al. 2007). This is probably related to the fact 
Table 1. Number of individuals of different classes seized by the SAyDS (Secretary of State for Environment and Sustainable Development of San Juan) per year in San Juan province.

\begin{tabular}{cccccc}
\hline \hline Year & Birds & Mammals & Reptiles & Amphibians & Total \\
\hline \hline $\mathbf{2 0 1 5}$ & 340 & 23 & 1 & 0 & 364 \\
$\mathbf{2 0 1 6}$ & 438 & 24 & 0 & 0 & 462 \\
$\mathbf{2 0 1 7}$ & 230 & 35 & 0 & 0 & 265 \\
$\mathbf{2 0 1 8}$ & 454 & 45 & 0 & 0 & 499 \\
$\mathbf{2 0 1 9}$ & 332 & 32 & 0 & 0 & 364 \\
TOTAL & $\mathbf{1 7 9 4}$ & $\mathbf{1 5 9}$ & $\mathbf{1}$ & $\mathbf{0}$ & $\mathbf{1 9 5 4}$ \\
\hline \hline
\end{tabular}

Table 2. Number and percentage of taxa that occur in San Juan province, number and percentage of taxa that were seized by provincial rangers, and number and percentage of threatened species seized in San Juan province.

\begin{tabular}{lccc}
\hline \hline Taxa & $\begin{array}{c}\text { Species occurring } \\
\text { in San Juan }\end{array}$ & $\begin{array}{c}\text { Taxa seized } \\
\text { in San Juan }\end{array}$ & $\begin{array}{c}\text { Threatened taxa seized } \\
\text { in San Juan }\end{array}$ \\
\hline \hline Amphibians & $16(4 \%)$ & $0(0 \%)$ & $0(0 \%)$ \\
Reptiles & $63(14 \%)$ & $1(2 \%)$ & $0(0 \%)$ \\
Mammals & $40(11 \%)$ & $15(25 \%)$ & $6(38 \%)$ \\
Birds & $304(71 \%)$ & $42(73 \%)$ & $10(62 \%)$ \\
TOTAL & $423(100 \%)$ & $58(100 \%)$ & $16(100 \%)$ \\
\hline \hline
\end{tabular}

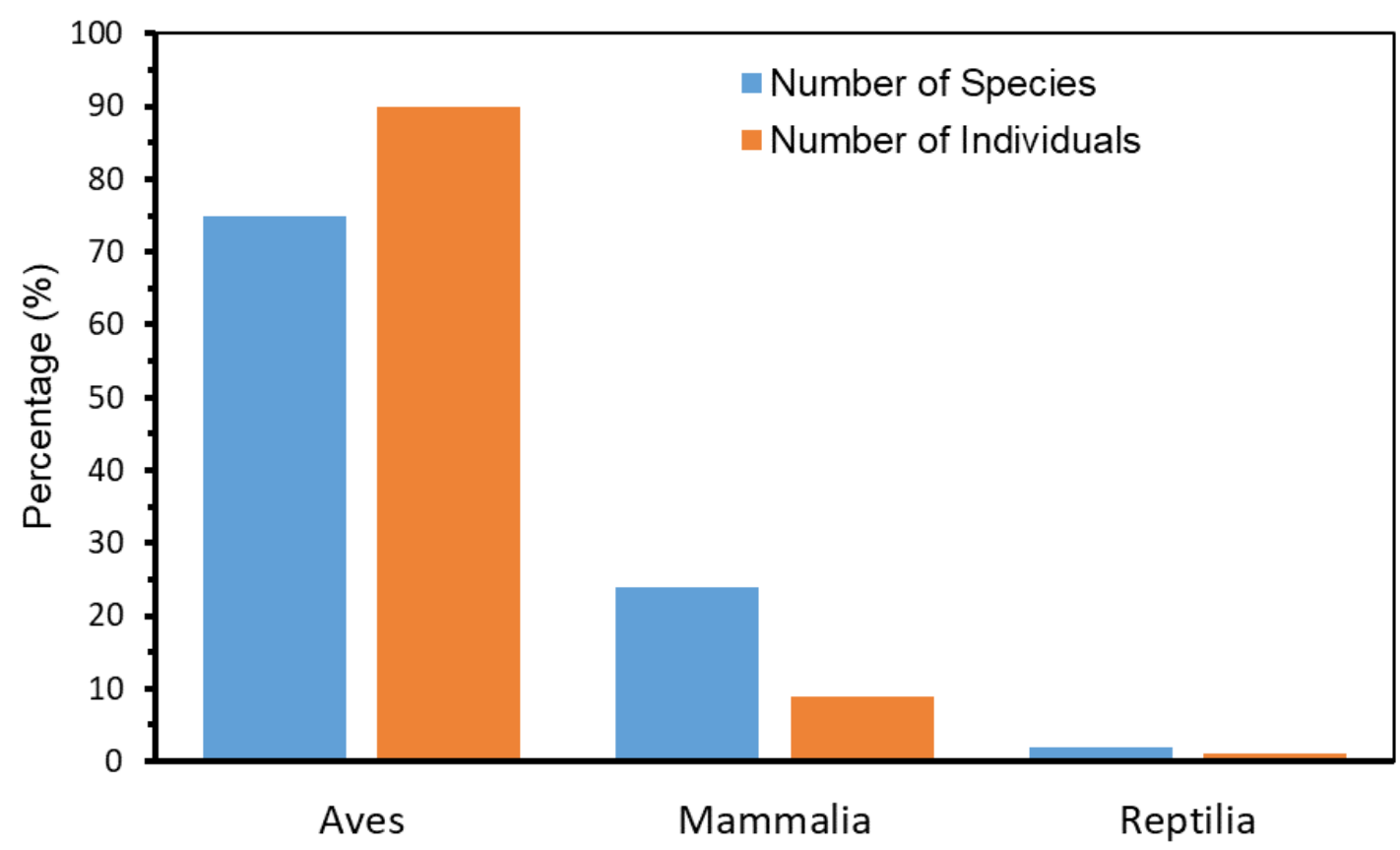

Figure 2. Percentage of different taxa seized, as number of species and number of individuals, by the provincial rangers (San Juan province), between 2015 and 2019.

that the most important objective of the hunting in San Juan is the use of animals for pets, and probably for sale. Regarding the current use of "boleadoras", although this is a pre-Columbian weapon, its use is 


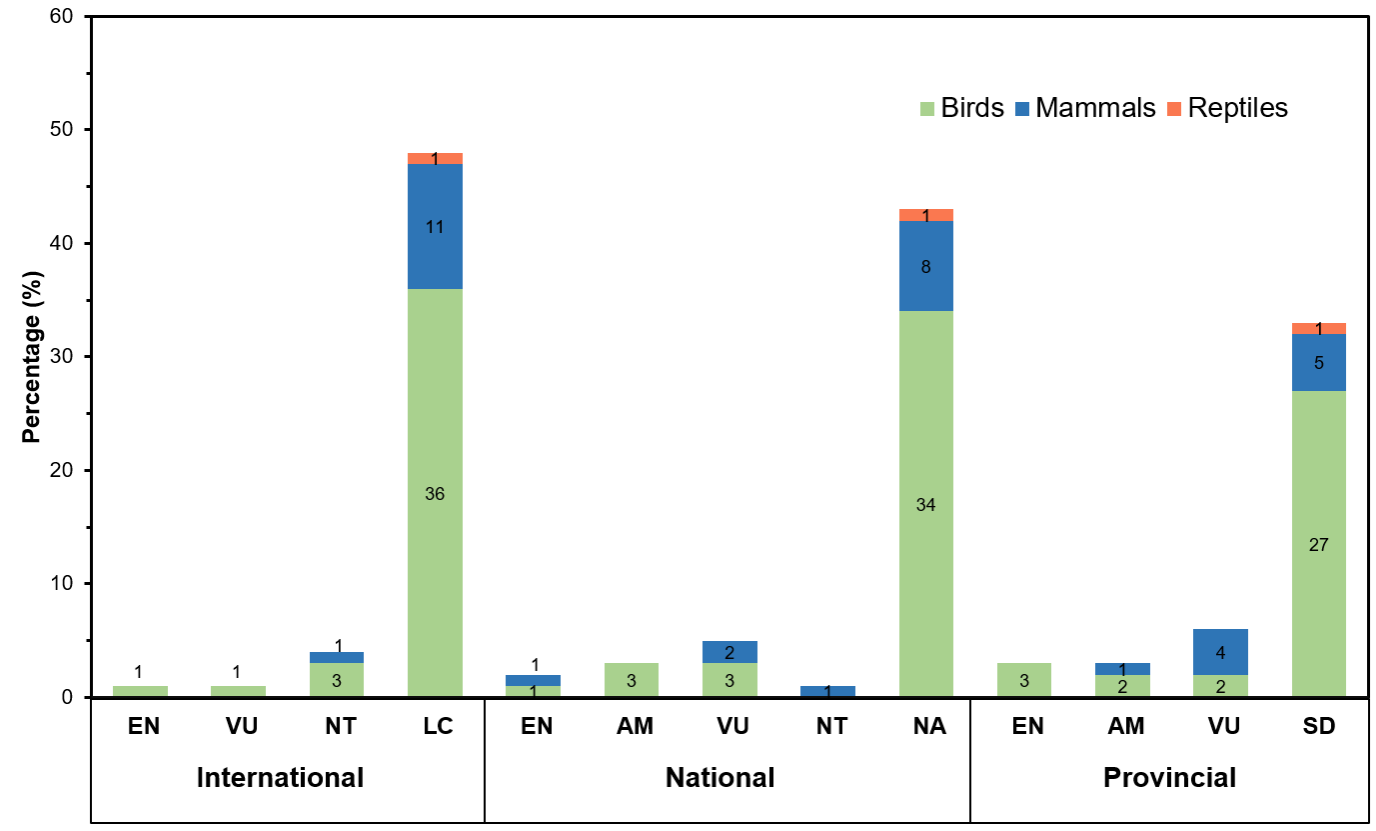

Figure 3. Percentage of different taxa seized in different conservation status, at the international level (IUCN), national level (Argentina) and province of San Juan level, between 2015 and 2019. International status: EN (endangered), VU (vulnerable), NT (near threatened), LC (least concern); National status: EN (endangered), AM (threatened), VU (vulnerable), NT (near threatened), NA (not threatened); Provincial status: EN (endangered), AM (threatened), VU (vulnerable), SD (Not evaluated).

Table 3. Number and percentage of hunting tools seized by provincial rangers in San Juan province, western Argentina.

\begin{tabular}{lcc}
\hline \hline Hunting tools used by poachers & Number of seized tools (2015-19) & Percentage(\%) \\
\hline \hline Sherman/Fox traps & 2 & 0.1 \\
Boleadoras & 7 & 0.4 \\
Slingshots & 8 & 0.4 \\
Knives & 22 & 1.2 \\
Searchlights for hunting & 6 & 0.3 \\
Greyhound dogs & 203 & 10.8 \\
Air rifles & 12 & 0.6 \\
Fire arms & 46 & 2.4 \\
Ammunition & 375 & 19.9 \\
Glue for trapping birds & 2 & 0.1 \\
Mist nets & 9 & 0.5 \\
Bird cages & 530 & 28.1 \\
Trap bird cages & 664 & 35.2 \\
TOTAL & 1886 & 100.0 \\
\hline \hline
\end{tabular}

deeply rooted in different areas of Argentina, including by criollo populations (Giardina et al. 2021).

Most of the taxa hunted were to be used or sold for the purpose of being used as pets. In San Juan society, it is still socially acceptable to have many birds as pets in homes, for bird traps to be sold in hardware stores, for children to use slingshots, and for the rural population to consume guanaco or vizcacha meat. This occurs despite its illegality, since in San Juan province the hunting and trade of native species is prohibited by current legislation (San Juan Law 6,663). It is essential not to underestimate the impact that these practices can have on wildlife populations, because unsustainable hunting for food 


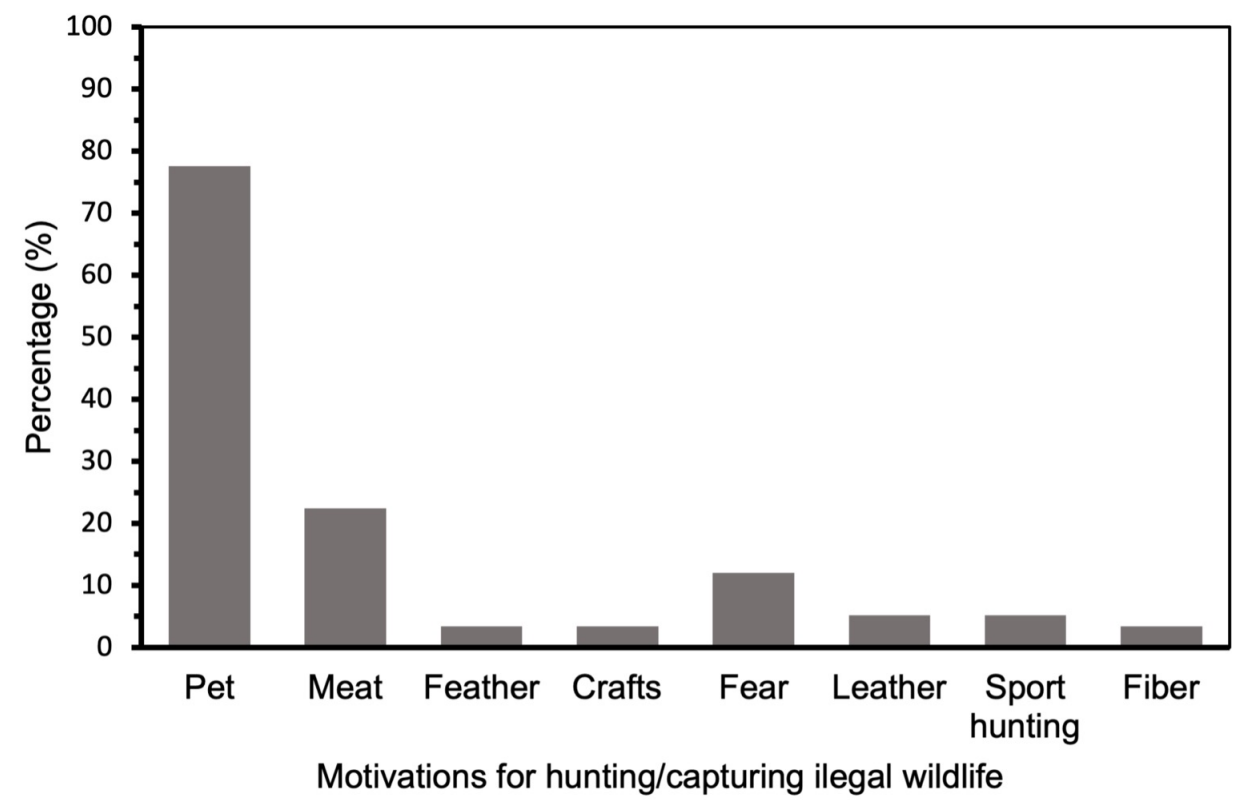

Figure 4. Percentage of different motivations for hunting wildlife taxa in central western Argentina, obtained through the use of official surveillance records as our data source (2015-2019).

and/or sport, together with the trapping of individuals for the pet trade, have been key factors in the extinction of many species, in particular birds, and today they continue to be among the main threats to the global populations of these taxa (BirdLife International 2018). In addition to this, studies carried out in Latin America showed that a wide variety of bird species are affected by illegal trade and that this business moves vast amounts of money (Ortiz-von Halle 2018; Regueira and Bernard 2012). Our data showed that between 2015 and 2019, the numbers of birds seized were higher than those of the other taxa. If we also analyze the hunting tools, we see that the two most confiscated items are traps and cages for birds. These data give an idea of how many individuals of wild birds are extracted from the wild to sustain their illegal trade in the province and perhaps in part of the country's networks whose main destination is usually the Buenos Aires markets (Richard et al. 2010). On the other hand, if we consider that some experts estimate that no more than $10 \%$ of all smuggled wildlife is seized, the numbers are expected to be much higher. As mentioned by Van Uhm (2016), "the confiscations reflect only a part of the illegal trade as a large part of this trade remains unreported or undiscovered, the so-called dark number".

Although we detected some seizures of species threatened with extinction, a large number of species under pressure from poaching and illegal wildlife trade in western Argentina are classified as "Least Concern".
This is probably a red flag since the illegality and secrecy of hunting and trade makes it difficult to estimate precisely the extent and impact of the activities. According to BirdLife International (2018), several abundant and well-known bird species are reaching the risk of extinction due to overexploitation and the degradation of their natural habitat. As an example, there is the case of the yellow-breasted bunting (Emberiza aureola), a species that was abundant in Eurasia, but that is currently critically endangered. Its population has fallen by $90 \%$ since 1980 due to illegal hunting as it is considered a delicacy in China. A closer example is the case of the yellow cardinal (Gubernatrix cristata), which occurs in the San Juan province. In addition to being the main factors threatening the species (MAyDS-AA 2017), hunting and trade have brought about an unexpected consequence, the hybridization between diuca males (Diuca diuca) and yellow cardinal females. The effects of hybridization of the yellow cardinal possibly adds up to the threat of poaching and trade, generating higher uncertainty regarding its conservation (Bertonatti and López Guerra 1997; Domínguez et al. 2016).

On the other hand, although in absolute numbers birds used as pets are the greatest victims of these illicit activities, our results suggest that mammals are likely the most affected taxon, based on the expected values of richness, and given that a higher proportion of poached mammals is threatened species. As other authors also observed at a regional level (McAllister 
et al. 2009; Vilela et al. 2009), we found that in San Juan great pressure is exerted on mammals, especially poaching for meat consumption and leisure. These species include, for example, guanacos (Lama guanicoe) from which ribs, legs and jerky have been seized (Campos et al. 2021). In addition, the fur of some carnivores was recorded, such as from puma (Puma concolor) and Geoffroyi's cat (Leopardus geoffroyi); the hunting of these species is probably opportunistic, for leisure, conflict or tradition. Other species of birds that are sought for their meat and eggs were also recorded, such as puna rhea (Rhea tarapacensis, Borghi et al. 2017) and greater rhea (Rhea americana). Moreover, some species are also used in local traditional medicine, mainly in the mountain area of the province. Among these, the main used species are Rhea tarapacensis, Lama guanicoe, Lama vicugna, Puma concolor, Lycalopex sp., and Lepus europaeus (Borghi et al. 2017; Hernandez et al. 2015).

The case of the vicuna, sought for having one of the finest fleeces in the world, highlights the importance of protection actions taken on time when faced with the pervasive problem of poaching. This species was on the brink of extinction in 1960 due to overexploitation, barely reaching 6,000 individuals at the global level. Strict conservation regulations achieved the recovery of wild populations and today they reach 250,000 individuals (McAllister et al. 2009). In addition to the direct elimination of individuals, there may be less obvious but impactful effects of illegal hunting and trade on populations. In areas where hunting is practiced, $70 \%$ of the guanacos (L. guanicoe) and vicuñas ( $L$. vicugna) flee when they detect the presence of humans, affecting their foraging time or altering their feeding areas and therefore their habitat preferences (selecting less productive but safer areas) (Cappa et al. 2017; Donadio and Buskirk 2006). This effect, especially in the arid or semi-arid landscapes where productivity of soils and food availability is low, can become a serious conservation problem.

With regard to reptiles, it is striking that in the official records there is only one individual, a rattlesnake (Crotalus durissus). This individual was killed, and probably the motivations for killing it were human fears or simple aversion. Although snakes are used in San Juan as pets, in general, the small network of pet hobbyists who use them as pets, capture them themselves, and do not participate in the same network of those that use other species as pets. Moreover, the land turtle (Chelonoidis chilensis), a species that is very frequently used as a pet in homes, was not among the species seized. Turtles are illegally removed from their habitat to be marketed as pets, and are frequently seized by national and other provincial authorities (Prado et al. 2012). Vilela et al. (2009) consider turtles to be a species highly sought by peo- ple from the drylands of Argentina. In addition, it is evident that this species is under pressure in the province because a large number of individuals often arrive, usually in very bad conditions, at the Faunístico, a "Center for the Conservation of Wild Fauna," after the owners decide to stop caring for them (com. pers. Silvina Adarvez). Based on the aforementioned, the lack of seizure data of this species may be due to different factors: the lack of complaints or denouncements (it is culturally accepted to have turtles as pets), they may not be perceived as a species that is the victim of illegal trafficking, and they are animals that are easily extracted and transported, mostly unnoticed.

Hunting wild animals and harvesting was the base of the economy of pre-Columbian inhabitants of the San Juan province, and these activities continued after the arrival of Europeans, but more commercially. An example of this was the exportation leather from young guanacos (chulengos), used to manufacture bedspreads during the 1970s, reaching maximum numbers of 60,300 skins per year (Vilela et al. 2009). Moreover, poaching is still a common practice in this region. There is great pressure on certain species, some detected in our study, like the greater rhea (Rhea americana), the puna rhea (Rhea tarapacensis), several birds, and other vertebrate species, and some not recorded, such as the Chaco tortoise (Chelonoidis chilensis). Poaching and illegal wildlife trade threaten not only the survival and conservation of species, but also the integrity of the ecosystems on which our health and well-being depend. If we look at the large sums of money that the wildlife trade moves, we see that large rewards are at stake against few or no fines. It is essential to combat these acts and for the law and public officials to start considering them as serious crimes (Bernal 2013; Bertonatti 2017). Our life and permanence as humans depend inexorably on biodiversity. Globally we are at a turning point. Unlike what happens in other countries (or even in some provinces in Argentina) where it is very difficult to recover the biodiversity lost as a result of bad decisions or omissions, today in San Juan province we have the advantage of still being in time to prevent and recover from these impacts.

This study presents information that can be very useful when planning biodiversity conservation strategies to fight against poaching and illegal wildlife trafficking in Argentina, activities that continue to be one of the main causes of biodiversity loss worldwide (Bennett and Robinson 2000a; Eliason 1999; Gavin et al. 2010; Maxwell et al. 2016; Van Uhm 2016). We believe that to achieve the conservation of species, it is essential to evaluate wild populations stocks to estimate the impact of poaching and tradeon the most seized species, and create adequate management plans 
for fauna in the country.

\section{CONCLUSION}

Our results highlight that the majority of the taxa seized were related to trapped animals (still alive; $78 \%$ ), while the remaining $22 \%$ involved killed animals. This suggests that in San Juan, illegallycaptured wildlife are used mainly as pets. The cases that stand out involve the benteveo ( $S$. aurantiirostris), the most hunted species in absolute numbers, with 689 individuals confiscated and which is present in $63 \%$ of the records analyzed; and the diuca (D. diuca), with at least 422 individuals extracted from their natural habitat, and present in $19 \%$ of the records analyzed. These species also had the highest seizure indexes, 100 and 42 respectively. Other animals are used as food, such as mammals - guanacos - and birds - both rheas ( $R$. americana and $R$. tarapacensis). In addition, carnivores are also poached, such as the puma, the apex predator of the region, and small wild cats like Geoffroy's cat (L. geoffroyi), the hunting of which is probably opportunistic, for leisure, conflict or tradition. Finally, it is important to highlight that "boleadoras", weapons used by native people, were seized by rangers, and are still used to hunt rheas by criollo people. This study presents information that can be very useful when planning biodiversity conservation strategies to fight against poaching and illegal wildlife trafficking in Argentina, for which we believe adequate management plans for the country's fauna are essential.

\section{ACKNOWLEDGEMENT}

This work was supported by Grant No. 22920160100038CO from CONICET (Consejo Nacional de Investigaciones Científicas y Técnicas, Argentina). We thank the Authorities of the Secretary of Environment and Sustainable Development of San Juan province (Ing. Jorge Scellato, Sr. Dardo Recabarren) for allowing us to access the information on records of crimes committed by poaching and the illegal wildlife trade, and to COMFAUNA (Comunidad de Manejo de Fauna Silvestre en la Amazonía y en Latinoamérica) and its Publications Committee for all their valuable comments and suggestions, which helped us to improve the quality of our manuscript. We also acknowledge to Hani Bizri and to two anonymous reviewers for their constructive comments and suggestions, and to Nicholas Basily for proofreading the English version. This publication is funded by the Gordon and Betty Moore Foundation through Grant No. GBMF9258 to the Comunidad de Manejo de Fauna Silvestre en la Amazonía y en Latinoamérica
(COMFAUNA).

\section{DATA AVAILABILITY}

The data used to support the findings of this study are available from the corresponding author upon reasonable request.

\section{CONFLICT OF INTEREST}

The authors have no conflicts of interest to declare.

\section{CONTRIBUTION STATEMENT}

Conceived of the presented idea: CEB, JM, SB.

Data collection: SB, JM.

Carried out the data analysis: CEB, SB.

Wrote the first draft of the manuscript: SB, JM.

Review and final writing of the manuscript: CEB, $\mathrm{JM}, \mathrm{SB}$

Supervision: CEB.

\section{REFERENCES}

Alves Barbosa JA, Nobrega VA, Alves RR da N (2011) Hunting practices in the semiarid region of Brazil. Indian Journal of Traditional Knowledge 10:486-490.

Alves RR, Mendonça LE, Confessor MV, Vieira WL, Lopez LC (2009) Hunting strategies used in the semi-arid region of northeastern Brazil. Journal of ethnobiology and ethnomedicine 5:1-16.

Arroyave FJ, Goyeneche OYR, Gómez MAB, Heredia RGH (2014) Tráfico ilegal de tortugas continentales (Testudinata) en Colombia: una aproximación desde el análisis de redes. Acta Biológica Colombiana 19:381-392.

Barbarán F (2017) Perception and use of birds in rural ecosystems of Salta, Jujuy and southern Bolivia. El Hornero 32:063-071.

Barnosky AD, Matzke N, Tomiya S, Wogan GO, Swartz B, Quental TB, Marshall C, McGuire JL, Lindsey EL, Maguire KC (2011) Has the Earth's sixth mass extinction already arrived? Nature 471:51-57.

Bennett EL, Robinson JG (2000a) Hunting of wildlife in tropical forests: implications for biodiversity and forest peoples. Environment Department Papers 76:1-42.

Bennett EL, Robinson JG (2000b) Hunting of wildlife in tropical forests: implications for bio- 
diversity and forest peoples. World Bank. Environment Dept Paper, Washington, DC:

Bernal WD (2013) Tráfico ilegal de flora y fauna: El problema de la diversidad de normas y regulaciones en nuestro país y la disyuntiva con la falta de penas más severas. Universidad Nacional de La Pampa, Facultad de Ciencias Económicas y Jurídicas, La Pampa. [https://repo.unlpam.edu . ar/bitstream/handle/unlpam/1320/e_bertra112 . pdf].

Bertonatti C (2017) Un muestreo del tráfico de especies en la Argentina durante el año 2016. Fundación de Historia Natural Félix de Azara, [Report].

Bertonatti C, López Guerra A (1997) Hibridación entre cardenal amarillo (Gubernatrix cristata) y diuca común (Diuca diuca minor) en estado silvestre, en la Argentina. Hornero 14:235-242.

BirdLife International (2018) El Estado de conservación de las aves del mundo: tomando el pulso de nuestro planeta. BirdLife International, Cambridge, Reino Unido.

Borghi CE, Hernandez J, Campos CM (2017) Recognition and uses of Rhea tarapacensis by residents in the catchment area of the San Guillermo Biosphere reserve (San Juan, Argentina). El Hornero 32:019-028.

Butchart SH, Walpole M, Collen B, Van Strien A, Scharlemann JP, Almond RE, Baillie JE, Bomhard B, Brown C, Bruno J (2010) Global biodiversity: indicators of recent declines. Science 328:1164-1168.

Campos CM, Moreno MC, Cappa FM, Ontiveros Y, Cona MI, Torres ML (2021) "Weaving" different knowledge systems through studying salience of wild animals in a dryland area of Argentina. Journal of Ethnobiology 41:292-306.

Cappa F, Campos V, Giannoni S, Andino N (2017) The effects of poaching and habitat structure on anti-predator behavioral strategies: A guanaco population in a high cold desert as case study. PLOS ONE 12:e0184018.

Carpaneto GM, Fusari A, Okongo H (2007) Subsistence hunting and exploitation of mammals in the Haut-Ogooue province, southeastern Gabon. Journal of anthropological Sciences 85:183-193.

Chebez JC, Chevez JC (2008) Los que se van: mamíferos. Editorial Albatros, Buenos Aires, Argentina.

Dirzo R, Young HS, Galetti M, Ceballos G, Isaac
NJ, Collen B (2014) Defaunation in the Anthropocene. Science 345:401-406.

Domínguez M, Reboreda JC, Mahler B (2016) Effects of fragmentation and hybridization on geographical patterns of song variation in the endangered yellow cardinal Gubernatrix cristata. Ibis 158:738-746.

Donadio E, Buskirk SW (2006) Flight behavior in guanacos and vicuñas in areas with and without poaching in western Argentina. Biological Conservation 127:139-145.

Eliason SL (1999) The illegal taking of wildlife: Toward a theoretical understanding of poaching. Human Dimensions of Wildlife 4:27-39.

Fraser H, Simmonds JS, Kutt AS, Maron M (2019) Systematic definition of threatened fauna communities is critical to their conservation. Diversity and Distributions 25:462-477.

Gavin MC, Solomon JN, Blank SG (2010) Measuring and monitoring illegal use of natural resources. Conservation Biology 24:89-100.

Giardina M, Otaola C, Franchetti F (2021) Hunting, Butchering and Consumption of Rheidae in the South of South America: An Actualistic Study. Ancient Hunting Strategies in Southern South America. Springer, pp. 159-174.

Giraudo AR, Arzamendia V, Bellini G, Bessa CA, Calamante CC, Cardozo G, Chiaraviglio de Torres M, Costanzo MB, Etchepare EG, Di Cola V (2012) Categorización del estado de conservación de las serpientes de la República Argentina. Cuadernos de herpetología 26:303-326.

Grisolia MJ, Grosskopf D (2021) Análisis de decomisos de fauna silvestre en Argentina durante el año 2020. Boletin Biodiversidad Neotropical 4:1-11.

Hernandez J, Campos CM, Borghi CE (2015) Medicinal use of wild fauna by mestizo communities living near San Guillermo Biosphere Reserve (San Juan, Argentina). Journal of Ethnobiology and Ethnomedicine 11:1-10.

Interpol (2012) World Model UN. Interpol., Lyon.

IUCN (2021) The IUCN red list of threatened species. [https://www.iucnredlist.org/ en] AccessedJuly11, 2021.

Jackson JE (1986) The hare trade in Argentina. Traffic Buletin 7:72.

Leite KCE, Seixas GHF, Berkunsky I, Collevatti RG, Caparroz R (2008) Population genetic structure 
of the blue-fronted Amazon (Amazona aestiva, Psittacidae: Aves) based on nuclear microsatellite loci: implications for conservation. Genet Mol Res 7:819-829.

Liddick DR (2011) Crimes Against Nature: Illegal Industries and the Global Environment: Illegal Industries and the Global Environment. ABC-CLIO.

Mares MA, Ojeda RA (1984) Faunal commercialization and conservation in South America. BioScience 34:580-584.

Maxwell SL, Fuller RA, Brooks TM, Watson JEM (2016) Biodiversity: The ravages of guns, nets and bulldozers. Nature 536:143-145.

MAyDS AA (2017) Categorización de las aves de la Argentina (2015). Buenos Aires, Argentina: Informe del Ministerio de Ambiente y Desarrollo Sustentable de la Nación y de Aves Argentinas.

McAllister RR, McNeill D, Gordon IJ (2009) Legalizing markets and the consequences for poaching of wildlife species: The vicuña as a case study. Journal of environmental management 90:120-130.

Nellemann C, Henriksen R, Kreilhuber A, Stewart D, Kotsovou M, Raxter P, Mrema E, Barrat S (2016) The rise of environmental crime: a growing threat to natural resources, peace, development and security. United Nations Environment Programme (UNEP).

Ni Q, Wang Y, Weldon A, Xie M, Xu H, Yao Y, Zhang M, Li Y, Li Y, Zeng B, Nekaris KAI (2018) Conservation implications of primate trade in China over 18 years based on web news reports of confiscations. PeerJ 6:e6069 DOI 10.7717 /peerj.6069.

Ojeda RA, Mares MA (1982) Conservation of South American mammals: Argentina as a paradigm. Mammalian biology in South America 6:505-521.

Ortiz-von Halle B (2018) Bird's-eye view: Lessons from 50 years of bird trade regulation. TRAFFIC, Cambridge, UK.

Periago ME, Chillo V, Ojeda RA (2015) Loss of mammalian species from the $S$ outh $A$ merican $\mathrm{G}$ ran $\mathrm{C}$ haco: empty savanna syndrome? Mammal review 45:41-53.

Pimm SL, Russell GJ, Gittleman JL, Brooks TM (1995) The future of biodiversity. Science 269:347-350.

Prado WS, Waller T, Albareda DA, Cabrera MR, Etchepare EG, Giraudo AR, González Carman V,
Prosdocimi L, Richard E (2012) Categorización del estado de conservación de las tortugas de la República Argentina. Cuadernos de Herpetología 26:375-388.

Regueira RFS, Bernard E (2012) Wildlife sinks: Quantifying the impact of illegal bird trade in street markets in Brazil. Biological Conservation 149:16-22.

Richard E, Zapata DC, Contreras MER (2010) Aportes al conocimiento de las estructuras de tráfico de fauna silvestre de Argentina. I. Relevamiento preliminar de la información y estructura interna del mercado. Revista UNR Ambiental 9:197-214.

SAyDS-San Juan (2011) Resolución Número 0656-11. Categorización de la Fauna Provincial. San Juan, Argentina.

SAyDS-SAREM (Eds) (2019) Categorización de los mamíferos de Argentina según su riesgo de extinción. Lista Roja de los mamíferos de Argentina. [https://cma. sarem.org.ar] Accessed July 11, 2021.

Schneider JL (2008) Reducing the illicit trade in endangered wildlife: the market reduction approach. Journal of Contemporary Criminal Justice 24:274-295.

Sosa-Escalante JE (2011) Aplicación de la ley para el combate del tráfico ilegal de vida silvestre en México: El caso de Charco Cercado. Therya 2:245-262.

Sousa JAC, Srbek-Araujo AC (2017) Are we headed towards the defaunation of the last large Atlantic Forest remnants? Poaching activities in one of the largest remnants of the Tabuleiro forests in southeastern Brazil. Environmental Monitoring and Assessment 189:129.

Van Uhm DP (2016) The illegal wildlife trade: Inside the world of poachers, smugglers and traders. Springer.

Vilela A, Bolkovic ML, Carmanchahi P, Cony M, de Lamo D, Wassner D (2009) Past, present and potential uses of native flora and wildlife of the Monte Desert. Journal of Arid Environments 73:238-243.

Wilkie DS, Bennett EL, Peres CA, Cunningham AA (2011) The empty forest revisited. Annals of the New York Academy of Sciences 1223:120-128.

WWF (2018) Informe Planeta Vivo 2018. Apuntando más alto. WWF, Gland, Suiza. [http://awsassets.wwf.es/downloads/ informe_planeta_vivo_2018.pdf]. 
Yéboué FK, Koffi M, Sylla I, Abe AI, Ahouty B, N'Djetchi KM, Simaro S, Konan T, Tidou SA, Béné J-CK (2020) Quantifying poached wildlife mammal species in Center-western region of Cte dIvoire. Journal of Ecology and The Natural Envi-

Received: 26 August 2021

Accepted: 20 December 2021

Published: 28 January 2022 
Table 4. List and number of individuals of taxa seized from 2015 to 2019, by the SAyDS (Secretary of State for Environment and Sustainable Development of San Juan) in San Juan province, western Argentina. Scientific and common names (in English and Spanish), conservation status: international (IUCN 2021), Argentine (MAyDS AA 2017; SAyDS-SAREM 2019) and San Juan province (SAyDS 2011), origin: native or exotic to the province, and motivation for hunting/capturing the taxa. Underlined taxon names refer to species that are under some category of threat. IUCN Red list Status: EN (endangered),

NT (near threatened), LC (least concern); National Status: EN (Endangered), A (Threatened), NT (Near threatened), VU (Vulnerable), LC (Least Concern), NA (Not Threatened); San Juan Status: EN (Endangered), AM (Threatened), VU (Vulnerable).

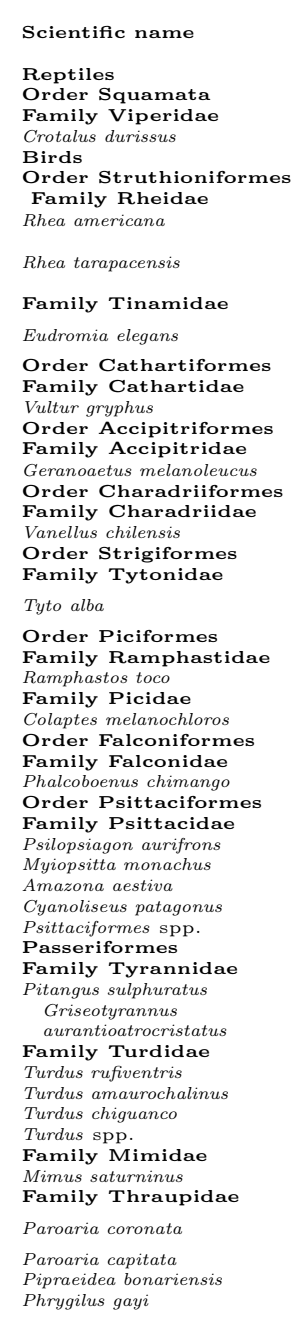

\begin{tabular}{|c|c|}
\hline$\underset{\text { in English }}{\text { Common name }}$ & $\underset{\text { in Spanish }}{\text { Common name }}$ \\
\hline South American rattlesnake & Cascabel \\
\hline Greater rhea & Ñandú, avestruz \\
\hline Puna rhea & Suri, choique \\
\hline Elegant crested tinamou & $\begin{array}{l}\text { Perdiz copetona, } \\
\text { martineta }\end{array}$ \\
\hline Andean condor & Cóndor andino \\
\hline Black-chested buzzard-eagle & Águila mora \\
\hline Southern lapwing & Tero \\
\hline Western barn owl & $\begin{array}{l}\text { Lechuza del campanario, } \\
\text { búho }\end{array}$ \\
\hline Toco toucan & Tucán, tucanico \\
\hline Green-barred woodpecker & Carpintero real \\
\hline Chimango caracara & Chimango \\
\hline $\begin{array}{l}\text { Mountain parakeet } \\
\text { Monk parakeet } \\
\text { Turquoise-fronted amazon } \\
\text { Burrowing parrot } \\
\text { Parrots }\end{array}$ & $\begin{array}{l}\text { Catita serrana } \\
\text { Cata } \\
\text { Loro hablador } \\
\text { Loro barranquero } \\
\text { Loros }\end{array}$ \\
\hline Great kiskadee & Pito juan, benteveo \\
\hline Crowned slaty flycatcher & Toquito \\
\hline $\begin{array}{l}\text { Rufous-bellied thrush } \\
\text { Creamy-bellied thrush } \\
\text { Chiguanco thrush } \\
\text { Thrush }\end{array}$ & $\begin{array}{l}\text { Zorzal chaqueño } \\
\text { Zorzal gato } \\
\text { Zorzal negro } \\
\text { Zorzal }\end{array}$ \\
\hline Chalk-browed mockingbird & Calandria \\
\hline $\begin{array}{l}\text { Red-crested cardinal } \\
\text { Yellow-billed cardinal } \\
\text { Blue-and-yellow tanager } \\
\text { Grey-hooded sierra finch }\end{array}$ & $\begin{array}{l}\text { Cardenal copete colorado } \\
\text { cardenal rojo } \\
\text { Cardenilla } \\
\text { Naranjero, sietecolores } \\
\text { Boquense }\end{array}$ \\
\hline
\end{tabular}

eizure

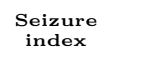

\section{IUCN
Red list
Status}

Nationa
Status

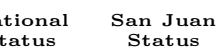

Native
or
Exotic

Motivations for

0.20

LC

1.40

NT

NT

LC

0.20

0.20

0.20

0.20

0.51

0.20

0.20

0.31
0.60
0.20
0.20

0.92

0.20

0.20
0.60
0.40

$-$.

1.56

3.15

3.15
0.20
1.32
7.41 


\begin{tabular}{|c|c|c|c|c|c|c|c|c|c|}
\hline Diuca diuca & Common diuca finch & Diuca & 422 & 41.6 & $\mathrm{LC}$ & NA & - - & $\mathrm{N}$ & Pet \\
\hline $\begin{array}{l}\text { Lophospingus pusillus } \\
\text { Poossiza ornato }\end{array}$ & $\begin{array}{l}\text { Black-crested finch } \\
\text { Cinnamon }\end{array}$ & $\begin{array}{l}\text { Soldaditio } \\
\text { Ladrillito }\end{array}$ & 10 & 1.70 & $\mathrm{LC}$ & NA & $\cdots$ & $\mathrm{N}$ & $\begin{array}{l}\text { Pet } \\
\text { Pet }\end{array}$ \\
\hline $\begin{array}{l}\text { Poospizaz orrnata } \\
\text { Micropingus torquatus }\end{array}$ & $\begin{array}{l}\text { Cinnamon warbling finch } \\
\text { Ringed warbling finch }\end{array}$ & $\begin{array}{l}\text { Ladrillito } \\
\text { Monterita }\end{array}$ & $\begin{array}{l}1 \\
8\end{array}$ & $\begin{array}{l}0.20 \\
0.57\end{array}$ & ${ }_{\mathrm{LC}}^{\mathrm{LC}}$ & $\begin{array}{l}\mathrm{NA} \\
\mathrm{NA}\end{array}$ & $\ldots$ & $\begin{array}{l}\mathrm{N} \\
\mathrm{N}\end{array}$ & $\begin{array}{l}\text { Pet } \\
\text { Pet }\end{array}$ \\
\hline 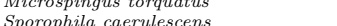 & 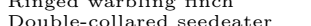 & Corbatita & 37 & $\begin{array}{l}0.58 \\
490\end{array}$ & $\mathrm{LC}$ & NA & $\cdots$ & ${ }_{N}^{N}$ & $\begin{array}{l}\text { Pet } \\
\text { Pet }\end{array}$ \\
\hline Catamenia analis & Band-tailed seedeater & $\begin{array}{l}\text { Piquito de oro } \\
\text { Prito dis }\end{array}$ & 16 & 2.90 & $\mathrm{LC}$ & $\mathrm{NA}$ & $\cdots$ & $\mathrm{N}$ & Pet \\
\hline $\begin{array}{l}\text { Coryphospingus cucullatus } \\
\text { Gubernatrix cristata }\end{array}$ & $\begin{array}{l}\text { Red-crested finch } \\
\text { Yellow cardinal }\end{array}$ & $\begin{array}{l}\text { Brasita de fuego } \\
\text { Cardenal amarillo }\end{array}$ & 3 & $\begin{array}{l}0.60 \\
2.17\end{array}$ & $\underset{\mathrm{EN}}{\mathrm{LC}}$ & $\begin{array}{l}\mathrm{NA} \\
\mathrm{EN}\end{array}$ & $\cdots$ & $\underset{N}{\mathrm{E}}$ & $\begin{array}{l}\text { Pet } \\
\text { Pet }\end{array}$ \\
\hline $\begin{array}{l}\text { Gubernatrrx cristatat } \\
\text { Saltator multicolor }\end{array}$ & $\begin{array}{l}\text { Yellow cardnal } \\
\text { Many-colored Chaco finch }\end{array}$ & $\begin{array}{l}\text { Cardenal amarillo } \\
\text { Vira vira }\end{array}$ & $\begin{array}{c}16 \\
9\end{array}$ & $\begin{array}{l}2.17 \\
1.65\end{array}$ & $\begin{array}{l}\mathrm{EN} \\
\mathrm{LC}\end{array}$ & NA & EN & $\mathrm{N}_{\mathrm{N}}$ & $\begin{array}{l}\text { Pet } \\
\text { Pet }\end{array}$ \\
\hline Saltator aurantiirostris & Golden-billed saltator & $\begin{array}{l}\text { Benteveo, } \\
\text { pepitero de collar } \\
\text { Jilguero, jilguerito, } \\
\text { jilguero de la sierra, }\end{array}$ & 684 & 100 & LC & $\mathrm{NA}$ & vu & $\mathrm{N}$ & Pet \\
\hline Sicalis spp. & Yellow finch & $\begin{array}{l}\text { canarito, } \\
\text { canarito de la sierra, } \\
\text { chamuchina, } \\
\text { jilguero, misto y mixto }\end{array}$ & 261 & 32.40 & $\cdots$ & - - & - - & $\mathrm{N}$ & Pet \\
\hline \multicolumn{10}{|l|}{ Family Passerellidae } \\
\hline $\begin{array}{l}\text { Zonotrichia capensis } \\
\text { Family Cardinalidae }\end{array}$ & $\begin{array}{l}\text { Anean sparrow, } \\
\text { rufous-collared sparrow }\end{array}$ & Chingolo & 5 & 0.71 & LC & NA & -- & $\mathrm{N}$ & Pet \\
\hline $\begin{array}{l}\text { Phencticus aureoventris } \\
\text { Pans }\end{array}$ & Black-backed grosbeak & Rey del bosque & 8 & 1.30 & $\mathrm{LC}$ & NA & EN & $\mathrm{N}$ & Pet \\
\hline 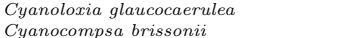 & $\begin{array}{l}\text { Glaucous-blue grosbeak } \\
\text { Ultramarine grosbeak }\end{array}$ & $\begin{array}{l}\text { Reina mora chica } \\
\text { Reina mora }\end{array}$ & $\begin{array}{l}1 \\
78\end{array}$ & $\begin{array}{l}0.20 \\
7.51\end{array}$ & $\begin{array}{l}\mathrm{LC} \\
\mathrm{LC}\end{array}$ & $\begin{array}{l}\mathrm{VU} \\
\mathrm{NA}\end{array}$ & AM & $\underset{\mathrm{N}}{\mathrm{E}}$ & $\begin{array}{l}\text { Pet } \\
\text { Pet }\end{array}$ \\
\hline $\begin{array}{l}\text { Family Icteridae } \\
\text { Agelasticus cyanopus }\end{array}$ & Unicolored blackbird & Tordo lagunero & 1 & 0.20 & $\mathrm{LC}$ & NA & & $\mathrm{E}$ & Pet \\
\hline $\begin{array}{l}\text { Leesses loyca } \\
\text { Family Fringillidae }\end{array}$ & Long-tailed meadowlark & Loica & $\frac{1}{5}$ & 0.85 & LC & NA & $\ldots$ & $\mathrm{N}$ & Pet \\
\hline Spinus magellanicus & Hooded siskin & $\begin{array}{l}\text { Cabecita negra, } \\
\text { jilguero cabeza negra }\end{array}$ & 17 & 2.37 & LC & $\mathrm{NA}$ & - - & $\mathrm{N}$ & Pet \\
\hline $\begin{array}{l}\text { Undetermined birds } \\
\text { Undetermined species } \\
\text { Mammals } \\
\text { Order Pilosa }\end{array}$ & & & 39 & $\cdots$ & $\cdots$ & - - & - - & $\cdots$ & Pet \\
\hline $\begin{array}{l}\text { Family Myrmecophagidae } \\
\text { Tamandua tetradactyla } \\
\text { Order Cingulata }\end{array}$ & Southern tamandua & Oso melero & 1 & 0.20 & LC & NT & $\cdots$ & $\mathrm{E}$ & Pet \\
\hline $\begin{array}{l}\text { Family Chlamyphoridae } \\
\text { Undetermined armadillo species } \\
\text { Order Carnivora }\end{array}$ & Armadillos & Quirquinchos & 18 & $\cdots$ & $\cdots$ & - . & $\cdots$ & $\mathrm{N}$ & Meat \\
\hline $\begin{array}{l}\text { Family Canidae } \\
\text { Lycalopex culpaeus }\end{array}$ & $\begin{array}{l}\text { Culpeo or Andean fox } \\
\text { Pampas fox }\end{array}$ & $\begin{array}{l}\text { Zorro colorado } \\
\text { Zorro gris }\end{array}$ & 1 & 0.20 & $\mathrm{LC}$ & NA & $\cdots$ & $\mathrm{N}$ & $\begin{array}{l}\text { Sport huntingFear } \\
\text { Sportigear }\end{array}$ \\
\hline $\begin{array}{l}\text { Lycalopex g gymnocercus } \\
\text { Family Felidae } \\
\text { Lepopardus geoffroyi }\end{array}$ & & & 1 & 0.20 & $J C$ & $N A$ & 2. & $N$ & Sport huntingFear \\
\hline $\begin{array}{l}\text { Leopardus geoffroyi } \\
\text { Puma concolor }\end{array}$ & $\begin{array}{l}\text { Geoffroy's cat } \\
\text { Cougar }\end{array}$ & $\begin{array}{l}\text { Gato montés } \\
\text { Puma }\end{array}$ & $\begin{array}{l}1 \\
5\end{array}$ & $\begin{array}{l}0.20 \\
0.81\end{array}$ & $\begin{array}{l}\mathrm{LC} \\
\mathrm{LC}\end{array}$ & $\begin{array}{l}\mathrm{NA} \\
\mathrm{NA}\end{array}$ & $\cdots$ & $\begin{array}{l}\mathrm{N} \\
\mathrm{N}\end{array}$ & $\begin{array}{l}\text { LeatherFear } \\
\text { Pet,Leather, } \\
\text { Snort buttinoFer }\end{array}$ \\
\hline $\begin{array}{l}\text { Order Artiodactyla } \\
\text { Family Tayassuidae } \\
\text { Pecari tajacu } \\
\text { Family Camelidae }\end{array}$ & Collared peccary & Pecarí & 1 & 0.20 & $\mathrm{LC}$ & $\mathrm{AM}$ & vu & $\mathrm{N}$ & MeatFear \\
\hline $\begin{array}{l}\text { Family Camelidae } \\
\text { Lama guanicoe }\end{array}$ & Guanaco & Guanaco & 41 & 6.09 & LC & EN & $\mathrm{vu}$ & $\mathrm{N}$ & Pet, Meat, \\
\hline $\begin{array}{l}\text { Lama vicugna } \\
\text { Order Rodentia } \\
\text { Family Caviidae }\end{array}$ & Vicuña & Vicuña & 1 & 0.20 & LC & $\mathrm{NA}$ & $\mathrm{AM}$ & $\mathrm{N}$ & Meat, Fiber \\
\hline Dolichotis patagonum & Patagonian mara & $\begin{array}{l}\text { Mara, liebre criolla, } \\
\text { liebre }\end{array}$ & 73 & 6.69 & NT & vU & vu & $\mathrm{N}$ & Pet, Meat, \\
\hline $\begin{array}{l}\text { Dolichotis salinicola } \\
\text { Family Chinchillidae }\end{array}$ & Chacoan mara & Conejo del palo & 1 & 0.20 & LC & $\mathrm{NA}$ & $\cdots$ & $\mathrm{E}$ & Meat, \\
\hline Lagidium viscacia & Southern mountain viscacha & Chinchillón o vizcacha & 1 & 0.20 & $\mathrm{LC}$ & NA & - - & $\mathrm{N}$ & Meat \\
\hline Lagostomus maximus & Plains viscacha & Vizcacha & 9 & 0.96 & LC & NA & $\mathrm{vU}$ & $\mathrm{N}$ & Meat \\
\hline $\begin{array}{l}\text { Exotic Species } \\
\text { Order Artiodactyla } \\
\text { Family Suidae } \\
\text { Sus scrofa } \\
\text { Order Lagomorpha } \\
\text { Family Leporidae }\end{array}$ & Wild boar & Jabalí & 2 & 0.25 & $\cdots$ & $\cdots$ & $\cdots$ & $\mathrm{E}$ & Meat \\
\hline $\begin{array}{l}\text { Leppus europaeus } \\
\text { Undetermined species }\end{array}$ & European hare & Liebre europea, liebre & 3 & 0.60 & $\cdots$ & $\cdots$ & $\cdots$ & $\mathrm{E}$ & Meat \\
\hline $\begin{array}{l}\text { Common name assigned to } \\
\text { D. patagonus and } L \text { e europaeus }\end{array}$ & Hare & Liebre & 7 & $\cdots$ & $\cdots$ & - & - - & - - & Meat \\
\hline
\end{tabular}

